\title{
INCREASED THE CAPACITY CBIA FACILITATOR THROUGH THE FORMATION AGENT Of CHANGE (AOC) IN THE USE ANTIBIOTICS IN TANJUNG GUNUNG VILLAGE CENTRAL BANGKA REGENCY
}

\author{
Rachmawati Felani Djuria \\ School of Health Polytechnics, Ministry of Health, Pangkalpinang
}

\begin{abstract}
Background: The results of a personal interview with the CBIA Facilitator that after the activities of the GKSO cadre formation in 2018, there were no more activities in the village due to busyness in preparing for accreditation at the puskesmas. Therefore, it is necessary to increase the capacity of CBIA Facilitators to activate the GKSO cadres despite the busyness. In addition, it is important to enable the GKSO cadre and CBIA facilitator to bring about changes in the quality of pharmaceutical services in the community. The purpose of this study is to increase the capacity of CBIA Facilitators in providing information to the community in Tanjung Gunung Village, Central Bangka Regency, Bangka Belitung Islands Province.

Subjects and Method: This was an experimental study using prestest-posttest only control group design. The study was conducted in Tanjung Gunung Village, Central Bangka Regency, Bangka Belitung Islands Province, form March-July 2019. Total of 3 pharmaceutical personnel and 24 community respondents Were selected in this study. The independent variable was capacity of CBIA Facilitators. The dependent variable was the use of antibiotic. The dara were analyzed decriptively.

Results: The CBIA facilitators capacity through Agent of Change (AoC) affected the changing of the antibiotics use among community.

Conclusion: The increasing of CBIA facilitators capacity through Agent of Change (AoC) also increasing the changing of the antibiotics use among community.

Keywords: agent of change, antibiotics, CBIA facilitators

\section{Correspondence:}

Rachmawati Felani Djuria. School of Health Polytechnics, Ministry of Health, Pangkalpinang. Jl. Telaga Biru I, Desa Padang Baru, Kecamatan Pangkalan Baru, Bangka Tengah, Bangka Belitung Province. Email: felanDJ87@gmail.com. Mobile: 08199559-6959.
\end{abstract}

